\title{
Pre-Sacral Giant Cell Tumour Excision through Posterior Approach
}

Ashith Rao, Sonik B Shah* and Prakash Samant

Department of Orthopedics, D Y Patil Hospital and Research Centre, Sector-5, Nerul (E), Maharashtra, India

*Corresponding author: Sonik B Shah, Department of Orthopedics, D Y Patil Hospital and Research Centre, Sector 5, Nerul (E), Maharashtra, India, Tel: 02227735901; E-mail: shah.sonik@gmail.com

Rec date: Aug 08, 2015; Acc date: Jul 21, 2016; Pub date: Jul 23, 2016

Copyright: (c 2016 Rao A. This is an open-access article distributed under the terms of the Creative Commons Attribution License, which permits unrestricted use, distribution, and reproduction in any medium, provided the original author and source are credited.

\section{Introduction}

Giant cell tumor (GCT) are well expansile, osteolytic lesion, with narrow transition zone at epiphysiometaphyseal region, commonly seen at ends of long bones accounting for approximately $5 \%$ of all primary bone tumors in adults. GCT in sacrum is the fourth commonest site after long end of bones, knee and radius, accounting for $1.7-8 \%$ of all GCTs [1-4]. Primary sacral tumor is rare and have incidence rate of 1 in 46,000 hospital admissions according to Ross and 1 in 30,000 according to Dockerty. GCTs are more common in Asia about $20 \%$ when compared to $4-5 \%$ in West [5-7].

As per the World health Organization (WHO) GCT is termed as "an aggressive potentially malignant lesion $[8,9]$. About $80 \%$ of GCTs have a benign course with a recurrence rate of $20 \%-50 \%$ out of which only $10 \%$ may undergo malignant transformation and $1 \%-4 \%$ gives rise to pulmonary metastases. They have also been reported to metastasize to regional lymph nodes, the mediastinum, pelvis scalp, bone and paraaortic nodes [9-11]. Herein we report a case of GCT of sacrum in a 35 year old female patient who presented with dull aching pain with no radiation making it unlikely to diagnose.

\section{Case Study}

A 35 year old lady hailing from Maharashtra, India presented with pain in the sacral area for the past 16 months. The pain at the beginning was dull aching in nature with no radiation to lower limb. However six months ago she complained of moderate to severe pain (7 on scale of 10) in the lumbosacral region, radiating posterolaterally from lumbar spine into bilateral thigh and subsequently, into bilateral crus. The patient also experienced change in bowel habits, alteration of bowel habits with no disturbance in sphinteric functions. Since the patient had vague history initially, a diagnosis of GCT wasn't suspected.

Various radiological imaging were carried out to reach to confirm the diagnosis.

Plain X-rays of Lumbar spine, sacrum and pelvis revealed a large expansile osteolytic lesion involving the sacrum, while computed tomography (CT) (Figure 1), revealed an abnormal destructive mass lesion of $82 \mathrm{~mm} 79 \mathrm{~mm}$ involving S2 and complete involvement of coccyx creating a mechanical pressure on rectum. MRI studies showed huge pelvis mass anteriorly abetting uterus, urinary bladder and rectum and posteriorly abetting bilateral gluteal maximus muscle though fat planes were maintained. Lateral extension upto the level of iliac vessels was observed. Bilateral sacroiliac joints appeared normal. The results of plain Xray, CT and MRI suggested a differential diagnosis of a Giant cell tumor.

General Examination was normal. Systemic Examination revealed a healthy young female with normal respiratory system, cardiovascular system, abdomen and gynecological examinations. Rectal examinations revealed a huge mass approximately $88 \mathrm{~cm}$ in diameter, irregular in surface, firm in consistency, non-tender, and fixed to sacrum and free from the rectal mucosa. Examination of anal sphincter tone and both lower limb were normal.

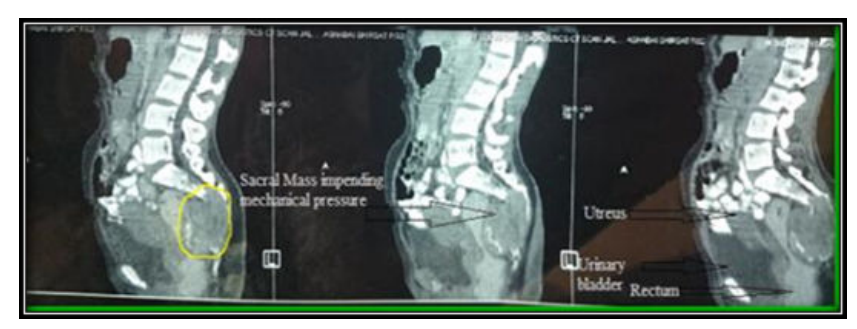

Figure 1: Computed topography pelvis showing osteolytic lesion.

Blood chemistry analysis revealed that the serum alkaline phosphatase, serum iron and C-reactive proteins concentration and the erythrocyte sedimentation rate were all within normal range.

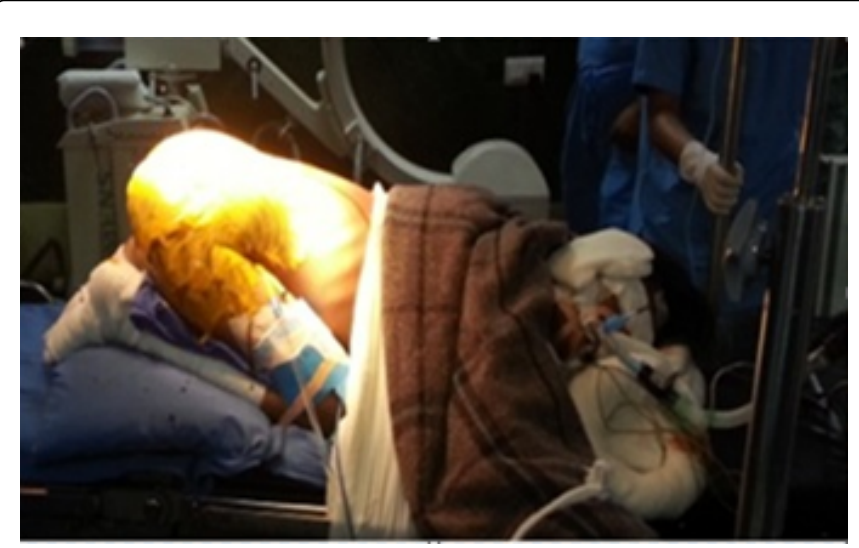

Figure 2: Geno pectoral position.

After a well informed consent was taken, patient was taken up for surgery. A Genu Pectoral position was given (Figure 2). A Mercedes Benz incision was taken extending longitudinally downwards from L4coccyx and then on both buttocks extending outwards upto level exposing entire mass. With help of blunt dissection with fingers, mass was separated from the overlying fascia along with adequate homeostasis.

Intra-operatively, there was destructive vascular lesion extending from S3-tip of coccyx, a mass well enclosed in a capsule not invading 
Page 2 of 3

surrounding structures (Rectum and lateral pelvic wall). End total mass was removed leaving behind a thin layer of capsule and pelvic floor muscle, to prevent damage to pelvic viscera (Figure 3). Histopathology findings reported benign GCT of the sacrum with no evidence of mitosis. The patient experienced delayed healing of the perineal wound that took 4 weeks (Figure 4).

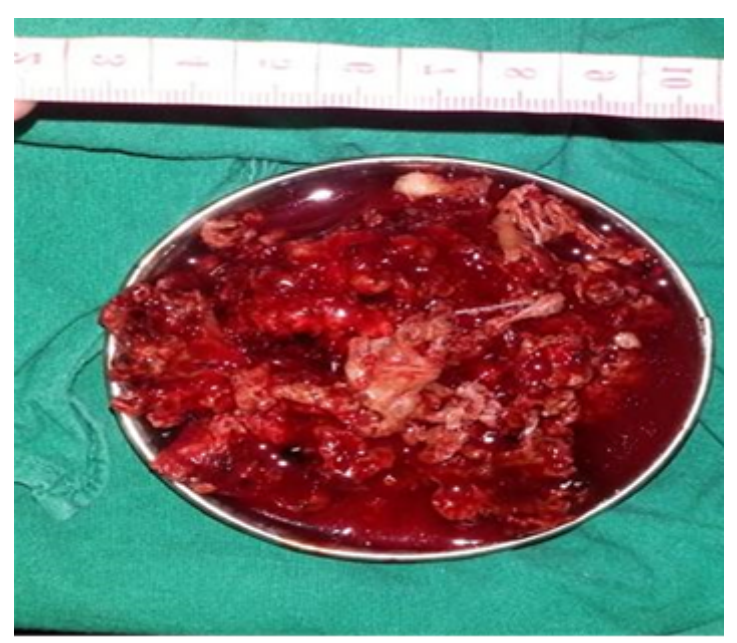

Figure 3: Excised tumour mass very friable mass, consisting of tumour and lytic bone.

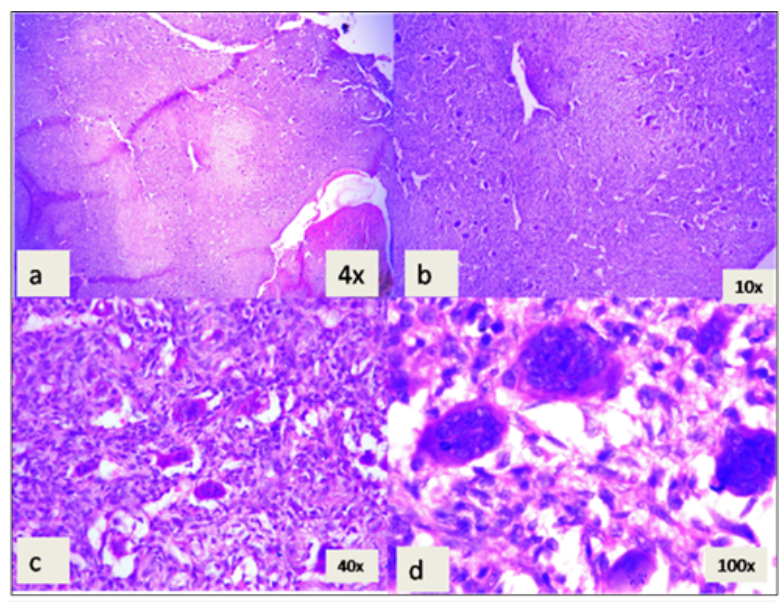

Figure 4: H\&E stained section shows lesional tissue with multiple giant cells in spindle cell stroma (a) Giant cells are seen under $4 \mathrm{x}$, (b) 10x, (c) 40x, (d)100x magnification.

\section{Discussion}

Giant cell tumor is a benign in histology however an aggressive tumor in nature, commonly presenting as lytic lesion in epiphysiometaphyseal region of long bones, whereas lesion of small bones and flat bones are a rare with an incidence of $2 \%-4 \%$ in mobile spine[ $[12,13]$ (Table 1).

\begin{tabular}{|l|l|l|}
\hline $\begin{array}{l}\text { Enneking } \\
\text { Classification }\end{array}$ & Stage 1 Latent & $\begin{array}{l}\text { Low biological activity, well } \\
\text { marginated, often incidental, } \\
\text { may resolve spontaneously }\end{array}$ \\
\cline { 2 - 3 } & Stage 2 Active & $\begin{array}{l}\text { Symptomatic, limited bone } \\
\text { destruction, may present with } \\
\text { pathological fracture }\end{array}$ \\
\cline { 2 - 3 } & $\begin{array}{l}\text { Stage } \\
\text { Aggressive }\end{array}$ & $\begin{array}{l}\text { Bone destruction/soft tissue } \\
\text { extension, requires complete } \\
\text { work up and removal with wide } \\
\text { margins to avoid possible } \\
\text { recurrence }\end{array}$ \\
\hline $\begin{array}{l}\text { Campannaci } \\
\text { Classification } \\
\text { (Radiological Grading } \\
\text { System) }\end{array}$ & Grade 1 & $\begin{array}{l}\text { Intramedullary lesion confined } \\
\text { to bone }\end{array}$ \\
\cline { 2 - 3 } & Grade 2 & Thinned, expanded cortex \\
\cline { 2 - 3 } & Grade 3 & Cortical breakout \\
\hline
\end{tabular}

Table 1: Various classifications have been followed to grade GCT. According to Enneking [9,14] Stage 2 and Campannaci [15] classification, the patient described above was classified as grade 2 . Jaffe, Dahlin and Lodwick Wilson Farrel graded GCT as benign, aggressive and malignant [15-18].

GCTs are closely related to aneursymal bone cyst differentiated with meiosis. They must be well differentiated from giant cells reparative granuloma, brown tumour, chondroblastoma, non-ossifying fibroma, Chondroma, Osteoid osteoma and osteoblastoma. Malignant GCTs are a rare entity with about $1 \%-3 \%$ presenting as primary tumors (malignant from onset) and $1 \%-6 \%$ as secondary. GCTs are histopathologically described as osteoclast like multinucleated giant cells with a moderately vascularized network of proliferating round, oval or spindle shaped stromal cells with or without mitosis. Radiologically they presents as an eccentric, well defined non sclerotic margin mass, only with a closed growth plate in plain X-rays. The hallmark of GCT is the Soap bubble appearance.

As there are many closely related differential diagnosis, GCTs are difficult to diagnose especially of rare sites like sacrum, as seen in this case. The ultimate diagnostic test is true cut biopsy from entire lesion, currently newer treatment modalities like Denusomab, intralesional curettage with polymethylmtharcylate (PMMA), arterial embolization, adjuvant therapies like use of phenol, $\mathrm{H}_{2} \mathrm{O}_{2}$ and liquid nitrogen are in practice that help in decreasing the recurrence of GCT [19-21]. Caution must be taking while performing any of the mentioned treatments as they involve dreadful complication of haemorrhage resulting in excessive blood loss during surgery and sacral nerve damage [22].

Due to the large grown mass and unavailability of arterial embolization at the institution, the patient was taken up for surgery wherein a posterior approach was considered and sufficient blood replacement was kept on standby.

\section{Conclusion}

GCT of the sacrum is a very rare clinical presentation and to diagnose such a case, thorough clinical examination, histopathological and radiological evaluation is required to rule out other differentials of an aggressive lytic lesion. Posterior approach with adequate blood standby helps in directly assessing the tumour mass along with reducing the risk of injuries to major vessels and abdo-pelvic viscera. It 
Citation: $\quad$ Rao A, Shah SB, Samant P (2016) Pre-Sacral Giant Cell Tumour Excision through Posterior Approach. J Trauma Treat 5: 321. doi:

Page 3 of 3

also helps in removal of entire mass and has wider operative accessibility to abdominal and pelvic cavity, hence reducing operative time.

\section{References}

1. Turcotte RE (2006) Giant cell tumor of bone. OrthopClin North Am 37: 35-51.

2. Campanacci M, Baldini N, Boriani S, Sudanese A (1987) Giant-cell tumor of bone. J Bone Joint Surg Am 69: 106-114.

3. Sung HW, Shu WP, Wang HM, Yuai SY, Tsai YB (1987) Surgical treatment of primary tumors of the sacrum. Clin Orthop Relat Res 215: 91-98.

4. Guo W, Ji T, Tang X, Yang Y (2009) Outcome of conservative surgery for giant cell tumor of the sacrum. Spine (Phila Pa 1976) 34: 1025-1031.

5. Ross ST (1948) Sacral and Presacral Tumors. Am J Surg 76: 687-693.

6. De Voe RW, Lovelady SB, Dockerty MB, Gray HK (1948) Pregnancy Complicated by Presacral Neurofibroma. Proc. Staff Meet, MayoClin. 23: 239.

7. Lim YW, Tan MH (2005) Treatment of benign Giant cell tumour in Singapore; annacad med Singapore 34: 235-7.

8. Schajowicz F (1993) Histological typing of bone tumours. In: Sobin LH (Ed). Berlin: Springer-Verlag (2ndedn) 20-22.

9. Szendroi M (2004) GCT of bone. J Bone Joint Surg [Br] 86-B:5-12.

10. Cheng JC, Johnston JO (1997) Giant-cell tumor of bone: prognosis and treatment of pulmonary metastases. ClinOrthop 338: 205-214.

11. Kay RM, Eckhardt JJ, Seeger LL, Mirra JM, Hok DJ (1994) Pulmonary metastasis of benign giant cell tumor of bone: six histologically confirmedcases, including one of spontaneous regression. Clin Orthop 302: 219-230.
12. Sung HW, Kuo DP, Shu WP, Chai YB, Liu CC, et al. (1982) Giant-cell tumor of bone: Analysis of two hundred and eight cases in chinese patients. J Bone Joint Surg Am 64: 755-761.

13. McDonald DJ, Sim FH, McLeod RA, Dahlin DC (1986) Giant-cell tumor of bone. J Bone Joint Surg Am 68: 235-242.

14. Enneking WF (1983) Musculoskeletal tumor surgery. Vol. 1, New York: Churchill Livingstone 1436-76.

15. Campanacci M, Giunti A, Olmi R (1975) Giant-cell tumours of bone: a studyof 209 cases with long term follow up in 130. Ital J Orthop Traumatol 1: 249-277.

16. Jaffe HL, Lichtenstein L, Portis RB (1940) Giant cell tumor of bone: itspathologic appearance, grading, supposed variants and treatment. Archives of Pathology 30: 993-1031.

17. Dahlin DC (1978) Bone tumours. (3rdedn) Springfield, Illinois: Charles C Thomas, 1978: 99-115.

18. Lodwick GS, Wilson AJ, Farrel C (1980) Determining growth rates of focal lesions of bone from radiographs: estimating rate of growth in bone lesions: observer performance and error. Radiology 134: 577-583.

19. Kreicbergs A, Lonnqvist PA, Nilsson B (1985) Curettage of benign lesions of bone. Factors related to recurrence. IntOrthop 8: 287-94

20. Lin PP, Guzel VB, Moura MF, Wallace S, Benjamin RS, et al. (2002) Longterm followup of patients with giant cell tumor of the sacrum treated with selective arterial embolization. Cancer 95: 13171325.

21. Wuisman P, Lieshout O, Sugihara S, van Dijk M (2000) Total sacrectomy and reconstruction: oncologic and functional outcome. Clin Orthop Relat Res 381: 192203.

22. Randall RL: Giant cell tumor of the sacrum. Neurosurg Focus 15: E13. 